\title{
Use of Information and Communication Technology (ICT) in Teaching and Learning in Nepalese Classroom: Challenges and Opportunity
}

\author{
Kamal Prasad Koirala \\ Lecturer, Science Education, Tribhuvan University \\ Gorkha Campus, Gorkha \\ Ph D Scholar, Graduate School of Education, Tribhuvan University, Nepal
}

\begin{abstract}
In post-modern era Information and Communication Technology (ICT) plays arduous role to make teaching and learning activities more meaningful and efficient. It is one of the most efficient tools as well as source of knowledge for advancing knowledge and skills. TPACK model are used for quality enhancement both in teachers and students in education at both schools and universities in Nepal. This paper presents the concepts of ICT and its roles for quality education at all level education in Nepal. It highlights the challenges facing in use of ICT in classroom of both schools and universities. It suggests how ICT can be used as a tools as well as source of knowledge to enhance education quality in classrooms. Problems such as lack of resources (viz. qualified teachers, hardware, software, electricity etc.) and poor program implementation strategies militate against these efforts. This paper recommends that both the government and non-government organizations should support in developing skilled human resources, providing electricity, and providing hardware and software resources to enhance the use of ICT as well as to produce knowledge at schools and universities of Nepal.
\end{abstract}

Keywords: ICT Education, Knowledge, Teaching eaning, Opportunity, Education System, Innovative DOI: $10.7176 / \mathrm{JEP} / 10-7-01$

Publication date:March $31^{\text {st }} 2019$

\section{Context of the study}

The long-term goal of Education in Nepal is to provide citizens with appropriate knowledge, skills and attitude require to work actively in the development of the country and to integrate Nepal into the global community through ensuring equitable access and quality education for all, particularly focusing on basic education. Education has been considered as a fundamental right of the people by the Constitution of Nepal 2015. Previous National Plans on education such as: Education for All (EFA), National Plan of Action/NPA (2001-2015), Three Year Plan (2011-2013) and School Sector Reform Plan/SSRP (2009-2015) and the current School Sector Development Plan(MOE, 2015) have introduced some strategies to ensure equitable access to education (Ministry of Education, 2015). The Government of Nepal (GON), Ministry of Education (MOE) has introduced various interventions in order to achieve the goal of education in Nepal. Use of Information and Communication Technologies ( ICT ) in education has been considered as one of the strategies to achieve the broader goals of education(MOE, 2013).

The School Sector Reform Program [SSRP] has envisioned for implementing and expanding ICT assisted teaching/learning process in all schools (MOE, 2015). ICT in education has been identified as an innovative and effective means of teaching and learning (Layton, 1987). Students of schools in urban areas have easier access to ICT whereas those students who are studying in remote areas have hardly any access to these technologies, which eventually is creating a digital divide (MOE, 2013). Besides, ICT can itself be a literacy that enables children, youth and every one to get benefit from the global environment the use of ICT in education shapes the teaching and learning activities (Lim, 2002).

The education system of Nepal has also been influenced by the changes made by ICT in the global context(Word Bank, 2006). The Government of Nepal, Ministry of Education, through National Curriculum Framework (NCF), has introduced ICT as a subject as well as ICT as a tool for instruction in school education(MOE, 2013). But in present days technology has transcended the role of facilitating knowledge and has indeed become a body of knowledge from which curriculum ought to be anchored (Koboja \&Ngussa, 2015) which indicates that ICT is not only the tools of education but education in ICT and role of technology as a fundamental source of knowledge apart from playing another significant role as medium of instruction.

In the formation of curriculum there should be consider the four pillars of philosophies. For generating the knowledge, technology play a crucial role which is justified from the following figure. 


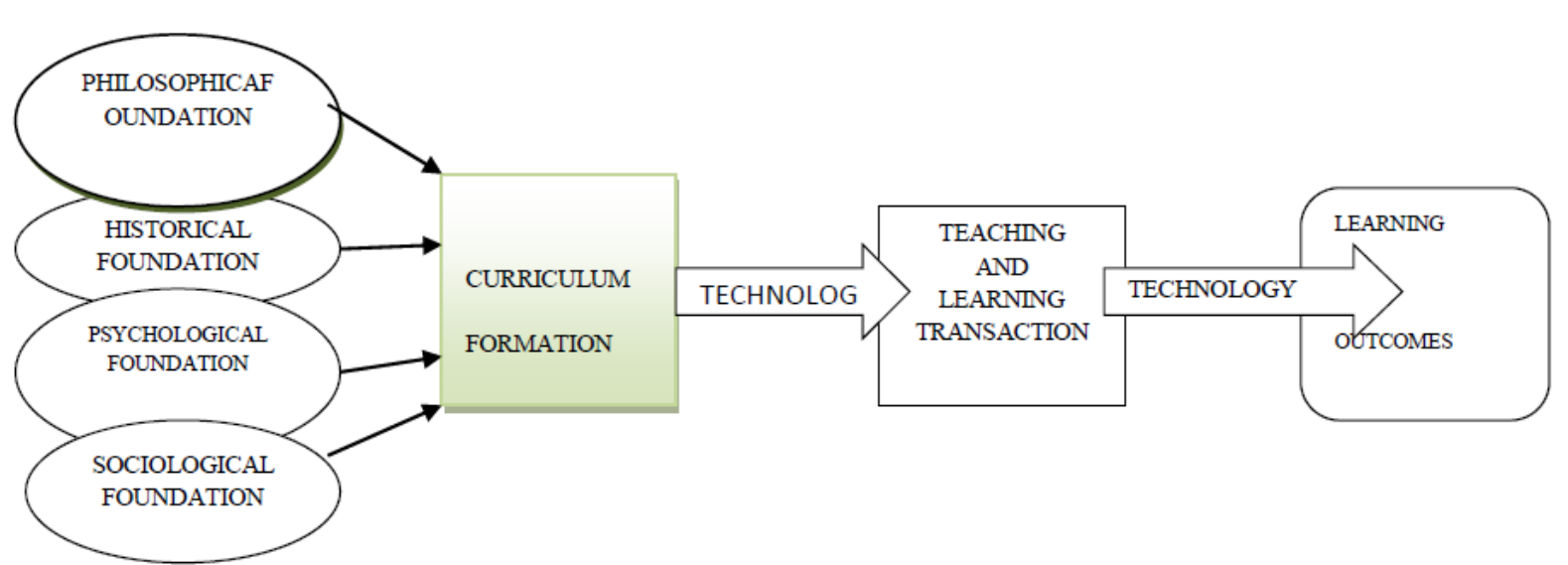

Fig 1. World view of curriculum formation (Koboja \& Ngussa, 2015)

This fig indicates that ICT is not only the tools for teaching and learning but it is necessary to incorporate in our education system to solve the educational problems and to generate the knowledge of everyday life (Koboja \&Ngussa, 2015).

In Nepal also some Universities/Colleges and schools have started ICT as a separate subject as well as ICT as a knowledge of teaching learning process (Shrestha, 2013). However, there is a need of streamlining these initiatives into a broader national framework in order to ensure equitable access to and quality of education.

Incorporation of technology in pedagogical content knowledge, Koehler and Mishra (2006) formulate a new conceptual framework which is shown in diagrammatic form is given below:

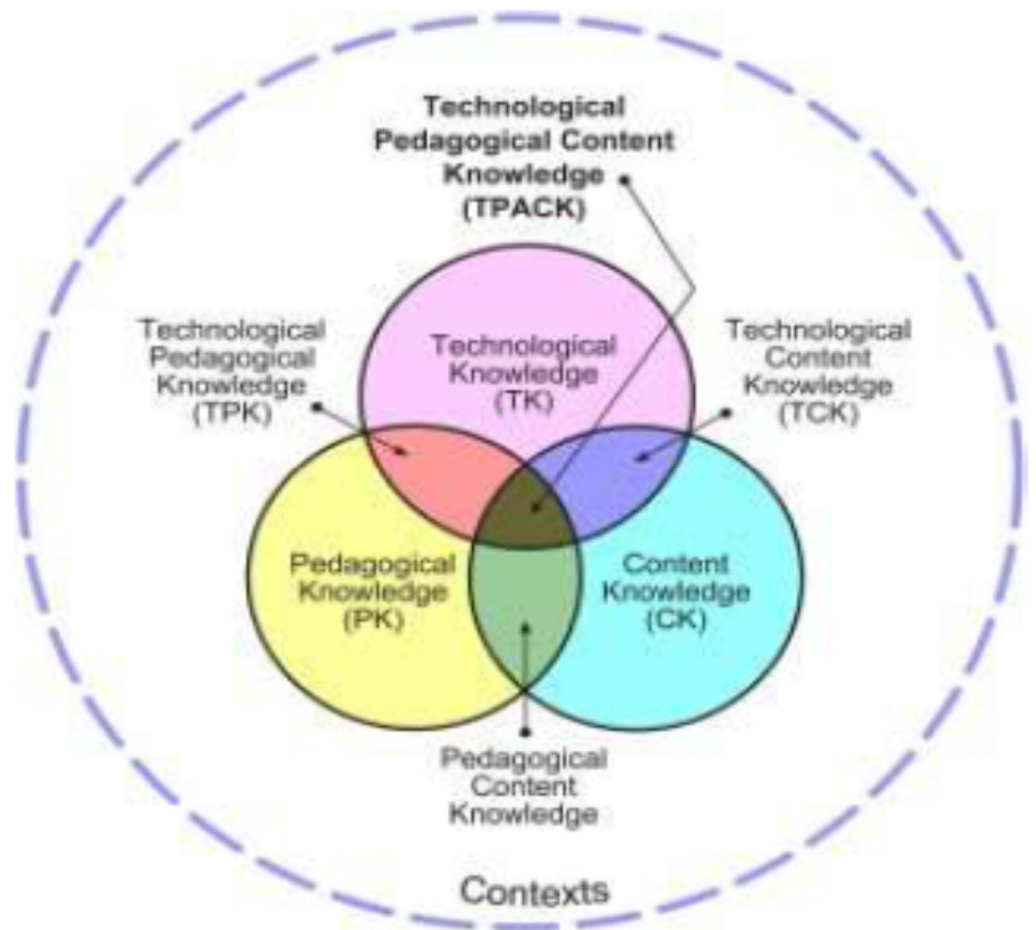

Fig.2. Technological Pedagogical and Content Knowledge (TPACK) Model.(Koehler \& Mishra, 2006 )

In figure some Technological, pedagogical and content knowledge are overlapped to each other in the centre of the circle gives interlinked knowledge to each other. TPACK framework can be used to design pedagogical strategies and an analytic lens to study changes in educators' knowledge about successful teaching with technology(Koehler \& Mishra, 2006 ).This type of theoretical model is seen applicable in the context of Nepal to strengthen in- depth knowledge in teachers and students through TPACK.

\section{ICT education in Nepal}

The need for ICT in Education has been realized with technological development in Nepal. As a result, some policies have been developed and some activities related to ICT have been carried out. ICT and computer education courses have been offered in general as well as in technical education. For example, National Centre for Educational Development (NCED) has been providing training to the teacher through National Radio and FM; Computer science has been taught as an optional subject in school (grades 9 to 12); Computer 
Engineering/Computer Science/ ICT programme in Bachelor's and Master's Levels are run by different colleges under various universities; various Training Institutes conduct technical education and vocational training courses in computer and ICT; Tribhuvan University has started Bachelor and Master in Education program in computer science.

MOE has implemented some of the programs related to ICT in Education. They are: one Laptop per Child (OLPC) pilot project in selected 26 schools of six districts; Lab model (computer sharing mechanism) Project in some schools and Internet connectivity to District Education Offices (DEOs) and schools (through matching fund to schools) and computer labs with internet connection from local ISPs (MOE, 2013). Similarly, Central Level Agencies under MOE, five Regional Directorates (REDs) and 75 District Education Offices have launched their web sites (MOE, 2013). Department of Education (DOE), with the involvement of some NGOs, has developed interactive digital learning materials for the students of grades 2 to 6 in Nepali, Mathematics, English and Science subjects.

During the fiscal year 2066/67 and 2067/68, the government of Nepal has supported for ICT related infrastructure and internet connectivity to 785 schools(MOE, 2016). Similarly, to improve educational management and delivery system, the Ministry of Education has provided some additional ICT related equipments to all District Education Offices and lunched website by each District Education Office(MOE, 2013).

However, such ICT equipments were mostly used for administrative purposes. This is due to the lack of contents as well as lack of proper skill and awareness to the teachers and education managers. For this a comprehensive policy and programme yet to be developed in order to provide relevant ICT education to the students and to use ICT for improving teaching learning activities. TPACK model is not used for teachers' professional development as well as student participatory learning.

In June 2012, the Ministry of Education has endorsed a guideline for the implementation of ICT in school education in Nepal. The institutional arrangements and other provisions included in this guideline are also taken into consideration while finalizing this Master Plan(MOE, 2013) however it is not clearly mentioned about the role of TPACK how to generate and provide the knowledge.

\section{Opportunity to use ICT in Nepal \\ Policies on ICT in Education}

There is not found consolidated ICT policy in education in Nepal in previous days. However, the IT Policy (2010, 2015), SSDP (2016/17-2022/23), Ministry of Education, ICT Master Plan 2013-2017 and Three Year Plan 20141016 of the GON have provided some policy and strategy for the development and integration of ICT in education (Transcend Vision Nepal, 2016). For example, IT Policy (2010) has the following policy provisions: Expansion of access of the Internet to all schools; Coordination and collaboration with national and international institutions to develop skilled human resources for continuous, relevant and quality education; Promotion of IndustryAcademia Collaboration (IAC); and formulation and implementation of special IT programme focusing on students, teachers and schools in order to develop competent human resources (MOE, 2012). The School Sector Development Plan (SSRP) states, ICT assisted teaching/learning will be implemented and expanded in all schools'. Similarly, SSDP has made a policy provision to develop ICT infrastructure in education and provide alternative modes of schooling through the use of ICT (MOE, 2016). One of the objectives of distance learning and distance education set by the MOE is to develop learning support materials to enhance quality of education through the use of ICT. The recent plan (three year plan, 2014-216) of GON (NPC, 2014) has included the following polices related to ICT in Education: schools will be encouraged to use ICT in education to increase access to quality education in rural areas, digital divide will be reduced, and ICT will be integrated in all aspects of education (Transcend Vision Nepal, 2016). Like that the implementation of the Information and Communication Technology in Education Master Plan (2013-2017) has increased access to computers and the internet in schools and universities, which allows for the scaling-up of the use of ICT in school education(Dhital, 2018).

The recent national educational plan is School Sector Development Plan, SSDP 2016-2023 (MoE, 2016). The ICT objectives of School Sector Development Plan (2016-2023) are as follows:

The appropriate use of ICT to improve classroom delivery by establishing an ICT enabling learning environment based on need and context. Appropriate development access to learning materials and supporting professional development packages and guidelines to ensure adequate capacity for incorporating these in the curriculum. Moreover, the use of ICT for the improvement and increased effectiveness and efficiency of overall educational governance and management.

SSDP's strategies for improving knowledge and the use of ICT are as follows :

a) Establish an ICT enabling learning environment by including ICT prerequisites as enabling conditions in government schools and the provision of ICT infrastructure and teaching-learning materials for pedagogy.

b) Establish ICT learning centers in schools with enhanced teaching-learning processes.

c) Incorporate ICT in the government curriculum through the development of professional development packages and guidelines. 
d) Develop need based educational materials for children with visual and hearing impairment and support computer education in government deaf schools.

e) Develop portals and websites including e-libraries.

f) Train teachers on the use of ICT in teaching and learning.

g) Develop online and offline training courses and materials (focusing on science, maths and English).

h) Prepare ICT teaching and learning materials, initially for science, Maths and English.

i) Develop and distribute subject-wise e-learning resources for students and teachers and establish a repository of them.

j) Strengthen school governance and management through a strengthened EMIS (Educational Management Information System), including the enhanced use of ICT to improve the EMIS and implement a unified accounting software, the Computerized Government Accounting System (CGAS) in MoE (MOE, 2016, Transcend Vision Nepal, 2016).

\section{Challenges to use ICT in education system of Nepal}

The development of information and communication technology in government education is faced with many challenges. So far, ICTs have not been used as a way of acquiring new knowledge and skills in schools of Nepal due to inadequacy of curriculum content and limited access to ICTs (Transcend Vision Nepal, 2016). Other challenges include inadequate funding, lack of basic infrastructure, lack of qualified personnel and lack of policy formulation and implementation (MOE, 2016). The major challenge in our context is the required physical infrastructure for implementing ICT. Nepal still experiences a lag in its implementation. This continue to widen the digital divide and the access to ICT facilities as a major challenge facing in Nepal (Transcend Vision Nepal, 2016). The following are challenges facing in implementation of ICT in government schools and universities of Nepal

\section{Lack of Qualified Teachers to Teach ICT in Schools and Colleges}

The demand for ICT learning has been stupendous and the number of teachers who are trained to teach ICT can not meet the demand. There are more students willing to be taught computing skills than there are teachers to transfer the skills.

\section{Lack of Electricity}

Many schools and colleges are still not yet connected to electricity; Nepal being a developing country, the government has not been able to connect all parts of the country to the national electricity grid. Inevitably, those schools that fall under such areas are left handicapped and may not be able to offer computer studies.

\section{Policy related}

Still the MOE has not come up clear policies the implementation of ICT in classrooms. The macro policy is there but it is equally important to transform them into micro policies so that each school and colleges will get an opportunity to have ICT facilities for their children.

\section{Lack of Computers (Hardware and Software Resources)}

Computers are still very expensive. Most of the schools and colleges don't have basic ICT resources such as computers, computer software and additional hardware resources. Though lots of efforts are made by the government agencies, individuals, corporate organizations, NGOs to donate computers to as many schools as possible.

\section{Financial}

Despite government commitments at various national and international forums to allocate $20 \%$ of the national budget and $4-6 \%$ of the GDP amount in education sector, the percentage of education budget is in decreasing trend from past several years. In the current fiscal year of 2017/18, out of the total national budget only 9.91 percent (about NRs 126 billion) is allocated for the education sector. This declination in education budget shows that the state does not hold education as a matter of priority. At a time when minimum enabling conditions do not exist in schools, it will be very difficult to introduce ICT on government expenses.

\section{Curricula related}

Nepal has a system of continuous improvement in curriculum although it cannot do so due t lacking of funding. So it should wait for at least 5 years in changing the curricula. The ICT will becoming in new shape every year but our curricula will be out of date by the time we install them based on existing efforts.

\section{Sustainability}

Twenty-two percent of the total education budget comes from multi-donor agencies. This is the only money the government has for development purposes. The danger is that the development projects will not continue after the projects are over. Thus the initiation of the government for ICT integration in education will follow the same suit.

\section{Conclusion}

In Nepal, in post-modern era, the initiation for ICT in school and university education is progressing. The implementation of the Information and Communication Technology in Education Master Plan (2013-2017) has 
increased access to Computers and the Internet in schools, which allows for the scaling-up of the use of ICT in school education. ICT is used as a tools in the previous days but it is necessary to develop it as a knowledge developmet.Morever, TPACK model guided to integrate technology, content and pedagogy in integrated form which is seen applicable in the context of Nepal. The recent national educational plan, School Sector Development Plan (2016-2023) integrates and focuses on use of ICT in government schools and universities. This demonstrates the commitment on the part of the government. Until now, the program is not in a rigid position for the use of ICT as knowledge generation and utilization. The roadmap has been made but it is seen that travel still takes a long time to use ICT as a form of knowledge. There are so many challenges and opportunity also to use ICT as a knowledge in Nepalese education system.

\section{Recommendation}

Political leaders and top bureaucrats not aware on dynamics and element of knowledge based society.

Training on e-Government, e-Services and Knowledge economy.

Target beneficiaries should be involved at the policy formulation stage ( policy always undisclosed material before announced)

Communication between beneficiary and policy implementers is important for monitoring successes.

Policy itself should clearly define the proper independent monitoring ( Important for both implementation and corruption control).

Reduce Time lag between the policy formulation and actual implementation.

ICT less attractive sector within government (unless there is an opportunity of procurement of hardware/services) . Special incentive for ICT workforce within government(Transcend Vision Nepal, 2016)

\section{Reference}

Baral, R. \& Bhurtyal, D. M.(2010). Nepal ICT Policy Challenges and opportunity. Forum for Information technology Nepal. University of Manchester

Dhital, H.(2018).Opportunities and challenges to use ICT in government school education of Nepal. International Journal of Innovative Research in Computer and Communication Engineering, 6(4),3215-3220, doi: 10.15680/IJIRCCE.2018.0604004

Koboja, J. M. \& Ngussa, B. M. (2015). Conceptualizing the place of technology in curriculum formation: A view of the four pillars of curriculum foundations. International Journal of Academic Research in Progressive Education and Development, 4(2), 54-67, doi: 10.6007/IJARPED/v4-i2/1728

Koehler, M. \& Mishra. P. (2006). Technological pedagogical and content knowledge: A framework of teacher knowledge. Teacher College Record, 108 (6), 1017-1054.

Layton, D.(1987).Innovation in science and technology education, New Delhi :Sterling Publishers Private Limited.

Lim, C. P.(2002). A theoretical framework for the study of ICT in schools. British journal of educational technology, 33(4),411-421, Blackwell Publishers.

Ministry of Education (MOE, 2009). School sector reform plan 2009-2015. Kathmandu: Government of Nepal, Ministry of Education.

Ministry of Education (MOE, 2016). School sector development plan 2016/17-2022/23. Kathmandu: Government of Nepal, Ministry of Education.

Ministry of Education(MOE, 2013). Information and Communication Technology in Education(Master plan $2013-$ 2017).Kathmandu: Author.

Shrestha, B. D.(2069). Role of information and ICT in developing University as a centre of excellence .Tribhuvan University, TU Bulletin Special 2012-13. TU Press, Kirtipur.

Transcend Vision Nepal (2016). A study on the use of ICT and its sustainability in school. Bhaktapur: Department of Education

World Bank (2006) Information and Communication for Development. Trends and Policies, Author: Washington, D.C. 